\title{
Sedimentation of the Kimmeridge Clay Formation in the Cleveland Basin (Yorkshire, UK)
}

\author{
Elizabeth Atar ${ }^{1,2, *(\mathbb{D})}$, Andrew C. Aplin ${ }^{1}$, Violaine Lamoureux-Var ${ }^{3}$, Christian März ${ }^{4}$ and \\ Thomas Wagner ${ }^{5}$ id \\ 1 Department of Earth Sciences, Durham University, South Road, Durham DH1 3LE, UK; \\ a.c.aplin@durham.ac.uk \\ 2 BP, Chertsey Rd, Sunbury-on-Thames, Middlesex TW16 7LN, UK \\ 3 IFP Energies nouvelles, 1 et 4 Avenue de Bois-Préau, 92500 Rueil-Malmaison, France; \\ violaine.lamoureux-var@ifpen.fr \\ 4 School of Earth and Environment, University of Leeds, Leeds LS2 9JT, UK; c.maerz@leeds.ac.uk \\ 5 Lyell Centre, Heriot-Watt University, Edinburgh EH14 4AS, UK; t.wagner@hw.ac.uk \\ * Correspondence: elizabeth.atar@bp.com
}

Received: 27 September 2020; Accepted: 29 October 2020; Published: 2 November 2020

\begin{abstract}
Fine-grained sedimentary successions contain the most detailed record of past environmental conditions. High-resolution analyses of these successions yield important insights into sedimentary composition and depositional processes and are, therefore, required to contextualise and interpret geochemical data which are commonly used as palaeoclimate proxies. The Kimmeridge Clay Formation (KCF) is a 500 m-thick mudstone succession deposited throughout the North Sea in the Late Jurassic and records environmental conditions through this time. Here, we present petrographic analyses (on 36 thin sections) on a $50 \mathrm{~m}$ section of a KCF core from the Cleveland Basin (Yorkshire, UK) to investigate controls on sedimentation in this region during the Tithonian, Late Jurassic. Facies descriptions demonstrate that deposition took place in a hydrodynamically variable environment in which the sediment origins, sediment dispersal mechanisms, and redox conditions fluctuated on the scale of thousands of years. Petrographic analyses show that the sediment comprises marine (algal macerals, calcareous fossils), detrital (quartz, clay, feldspar), and diagenetic (dolomite and authigenic kaolinite) components and that several sediment dispersal mechanisms influenced deposition and facilitated both the supply and preservation of terrestrial and marine organic material. This work provides a framework for the interpretation of geochemical palaeoclimate proxies and reinforces the importance of looking at the rock when interpreting whole-rock geochemical data.
\end{abstract}

Keywords: mudstone; Kimmeridge Clay Formation; depositional environment; sedimentation

\section{Introduction}

The Kimmeridge Clay Formation (KCF) contains one of the most complete records of marine environmental conditions in northwest Europe in the Late Jurassic. As such, it has been the subject of great interest over the past century [1-7]. Geoscientists continue to study the KCF using techniques ranging from sedimentology [8-10], geochemistry [6,11-15], to palaeontology [16-19], and climate modelling [20-23], in an effort to correlate deposits, elucidate depositional controls and reconstruct global climate conditions. Characterisation of the sediment facilitates the interpretation of ancient depositional environments, which provide a unique and important insight into global climate and carbon cycle dynamics [24]. However, lateral sediment transport and potentially multiple episodes of sediment remobilisation prior to deposition means that mudstones may record palaeoenvironment conditions from other areas of the ocean with little or no evidence of long-range transport; therefore, 
we need a thorough understanding of the physical processes and sources of the sediment before any conclusions are drawn from geochemical, palaeontological, or wireline analyses concerning temporal changes in palaeoenvironment [25-27].

Improved thin section preparation and analysis of very fine-grained $(<4 \mu \mathrm{m})$ sediment has revealed intricate compositional, textural, and structural heterogeneities far beyond the traditional interpretations of apparently homogenous mudstone deposits, demonstrating the importance of analysing fine-grained sediment across variety of scales, from nanometres to metres [10,26,28-34]. Lazar et al. (2010) [10] demonstrated this for the KCF through an extensive examination of a 10-metre thick section from Clavell's Hard, Southern England [10]. This study is, to date, the most high-resolution analysis of the KCF; 12 lithofacies are described and defined with reference to composition, texture, bedding, and grain origin, and interpreted in the context of a dynamic depositional environment. The authors identify several different sources of the mud fraction of the succession, including allochthonous components such as siliciclastic detritus and relict lithic grains, and authochthonous products such as algal material, which are dispersed through several different mechanisms, namely suspension settling, organo-mineral aggregate and pellet formation, sediment transport, and bioturbation [10]. They conclude that a complex interaction of multiple processes was responsible for the deposition of the KCF.

The aim of the present study is to conduct a detailed lithofacies analysis of a $50 \mathrm{~m}$ section of the Tithonian KCF that spans the Pectinatus pectinatus to the Pectinatus wheatleyensis ammonite zones and that was deposited in the Cleveland Basin, Yorkshire. The studied interval is partly time-equivalent to Lazar et al.'s (2010) [10] study in the Wessex Basin, providing an opportunity to compare contemporaneous deposits over $400 \mathrm{~km}$ apart and revisit the petrographic work in the context of modern understanding.

\subsection{Geological Setting}

In the Late Jurassic, atmospheric carbon dioxide concentrations were up to four times higher than at present [22], the climate was hot and humid [23] and there was no ice at the poles [35]. Deposition of organic carbon-rich sediments was widespread; in Europe, these are the Tojeira Shales in Portugal, the Kimmeridge Clay, Draupne, Mandal, and the Spekk Formation in the North Sea, the Hekkingen Formation in the Barents Sea, and the Agardhfjellet Formation in Svalbard [36-41]. Further afield, similar organic-rich strata are the Egret Member, the Spiti Shales, Kashpir oil shales, the Hanifa Formation, Haynesville Shale, and the Madbi Formation in Canada, Nepal, Russia and Siberia, Saudi Arabia, the USA, and Yemen, respectively [42-47].

The KCF has been correlated across the UK sector of the North Sea $[48,49]$. It was deposited in the shallow, epicontinental Laurasian Seaway connecting the Boreal and Tethyan Oceans along the Viking Corridor [50]. Formed because of subsidence associated with North Atlantic Rifting [51], the Laurasian Seaway comprised a series of interconnected basins, two of which were the Wessex Basin, where the KCF type section was deposited, and the Cleveland Basin (Figure 1a,b). The Cleveland Basin is a small extensional basin bound to the north by the Mid North Sea High, to the west by the Pennine Hills, to the East by the Sole Pit Basin and to the south by the Market Weighton High [52]. Middle Jurassic Central North Sea Forties-Piper volcanic activity caused south-westward tilting of the Cleveland Basin and rapid subsidence [53]. After the slowing of regional uplift, continuation of marine transgression, and east-west trending faulting in the Vale of Pickering, rapid marine sedimentation took place in the Cleveland Basin leading to the deposition of the Kimmeridge Clay Formation [52]. Water depths in the Cleveland Basin have proven difficult to establish with levels ranging from tens of metres [54-56] to hundreds of metres [3,5,57]. Study of the water depths in the Cleveland Basin in the Tithonian have not been revisited in the context of the modern shift in mudstone sedimentology that demonstrated that not all mudstones are deposited in "deep water". 
(a)

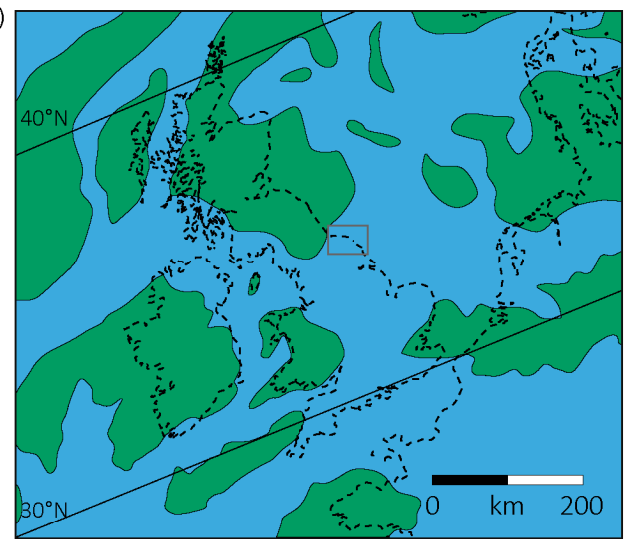

Key

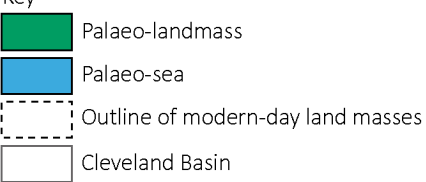

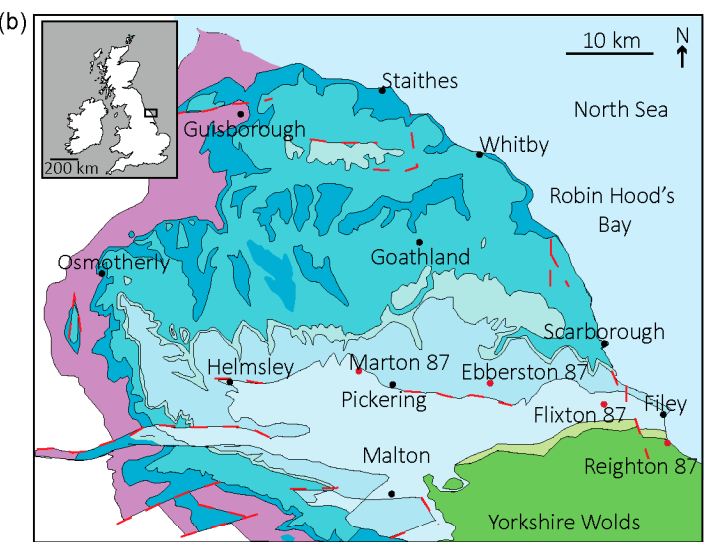

Key

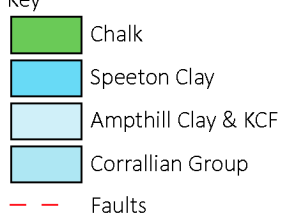

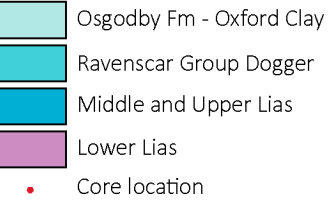

Figure 1. (a) Palaeogeographic map of North West Europe during the Kimmeridgian stage modified from Turner et al. (2019) [36] reproduced with permission after Atar et al. (2019b) [15]. (b) Geological map of the Cleveland Basin (Yorkshire, UK) after Powell (2010) [52], reproduced with permission after Atar et al. (2019a) [14]. The Marton 87, Ebberston 87, Flixton 87, and Reighton 87 cores are marked by red dots on the map.

\subsection{Previous Work on the Ebberston 87 (EB87) Core}

The EB87 Core is one of four cores drilled in the Cleveland Basin (Figure 1b) in a joint venture between the Institut Français du Pétrole (now IFPEN), the British Geological Survey and the Société Nationale Elf Aquitaine (SNEA) in the 1980s [5]. The project aimed to explore the controls on organic material enrichment across a basin. The four cores were correlated using ammonite biostratigraphy and downhole gamma ray logs [5]. The cores from this project were analysed using geochemical and microscopy work that characterised the organic matter, sulphur contents, mineralogy of the samples, and trace element contents [5,58-64]; however, while most of this earlier work provides excellent context, it focused on the adjacent cores and a different stratigraphic interval (Lower Jurassic) so is not directly relevant to the present study.

The Kimmeridge Clay Formation was reported to be vertically and horizontally homogenous across several $100 \mathrm{kms}[5,65]$, with sedimentological variation difficult to recognise in hand specimen. X-ray diffraction (XRD) and scanning electron microscope (SEM) data demonstrated clay minerals, quartz, organic material, and calcite to be the main sedimentary components [5]. Interpretations at that time suggested that the KCF was deposited below storm wave base with algal blooms resulting from ocean overturning [59]. Correlation of the EB87 Core to the more proximal Boulonnais section in Northern France indicates that total organic carbon (TOC) variation is not directly linked to sequence stratigraphy-derived relative sea-level changes but that marine transgressions acted to strengthen climate signals [60]. The lack of a direct causal mechanism between sea-level and enrichment of organic material is further supported by an alternative sea level reconstruction [66].

Figure 2 shows a lithology log of the studied section of the EB87 Core that was digitised from the IFPEN archives. This log was drawn by inspecting hand samples of the core, soon after the core was drilled. Sedimentation rates (uncorrected for compaction) for the studied interval of the EB87 core were calculated using the ammonite zonal boundaries from the Geological Timescale [67] and are $6.6 \mathrm{~cm} / \mathrm{ky}$ for the Pectinatus wheatleyensis zone, $5.1 \mathrm{~cm} / \mathrm{ky}$ for the Pectinatus hudlestoni zone, and $4.1 \mathrm{~cm} / \mathrm{ky}$ for the Pectinatus pectinatus zone [15]. It is important to note that the calculated sedimentation rates are crude approximations and carry large uncertainty inherent in biostratigraphical dating upon core material. 


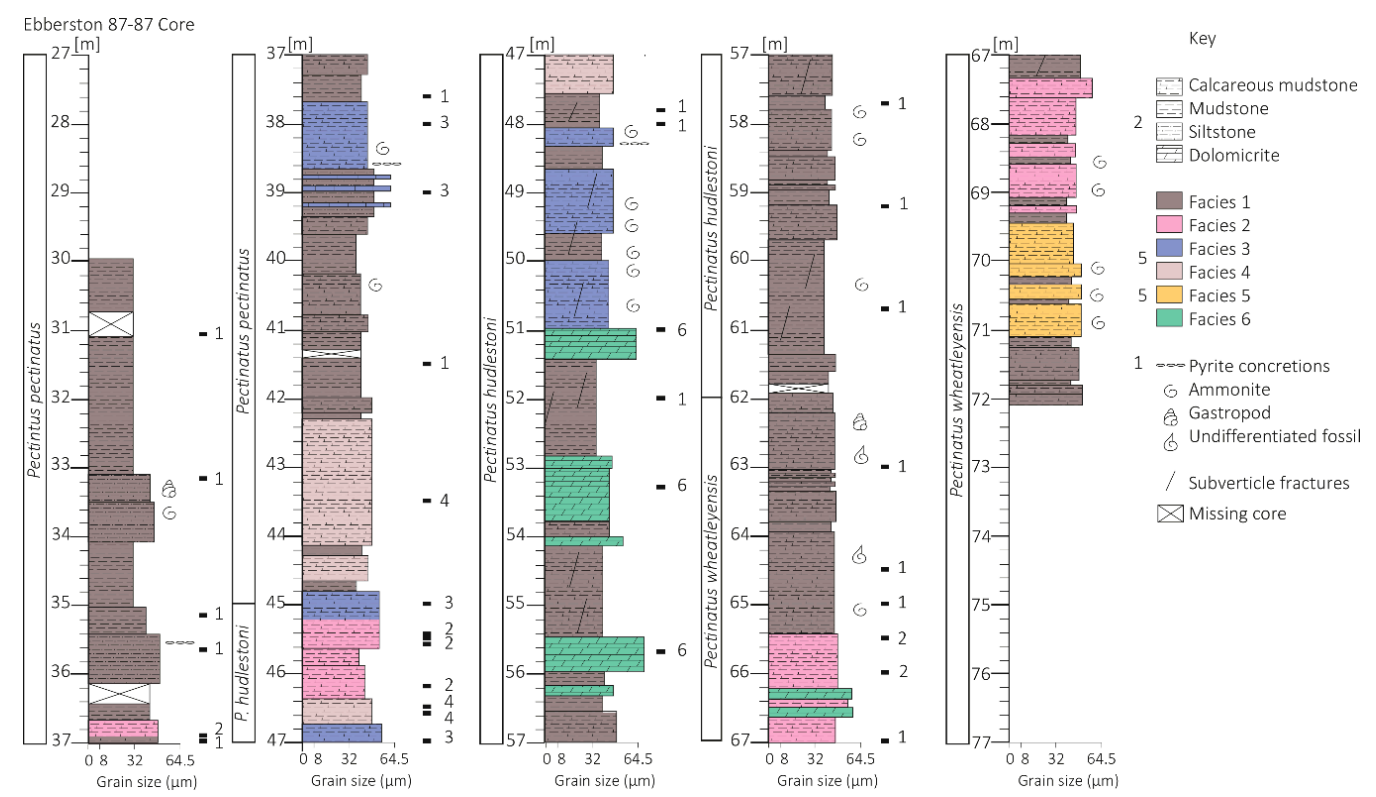

Figure 2. Lithographic log of the EB87 Core, redrawn from the IFPEN archives. Vertical unit is meters below surface. The black horizontal lines mark the location of thin sections and the numbers next to them indicate the facies defined in the present study. Facies 1 = Clastic-detritus-rich medium mudstone, Facies 2 = Organic material and calcareous pellet-rich, laminated mudstone, Facies 3 = Coccolith-dominated medium mudstone, Facies 4 = Agglutinated foraminifera bearing, medium to coarse, carbonaceous mudstone, Facies $5=$ Biogenic detritus dominated, fine to medium mudstone, and Facies 6 = Carbonate-cemented, fine to medium mudstone. The IFPEN lithographic log and the petrographic data have been combined to extrapolate the facies model over the whole core; this interpretation is colour coded on the log.

\section{Materials and Methods}

Thirty-nine samples were collected from the Ebberston 87 Core in the IFPEN core repository in Chartres, France, according to lithological variability (Figure 2) and prepared as thin sections. Samples were prepared to $30 \mu \mathrm{m}$ thickness and polished with $1 \mu \mathrm{m}$ diamond paste. Examination and imaging of the thin sections was conducted on a Leica DM750P microscope (Leica, Wetzler, Germany) fitted with a Leica ICC50 HD camera (Leica, Wetzler, Germany). Samples were then coated with $30 \mathrm{~nm}$ of carbon before being analysed on a Hitachi SE-70 High Resolution Analytical Scanning Electron Microscope (SEM) (Hitachi High-Tech Corporation, Tokyo, Japan). The SEM was operated at $15 \mathrm{kV}$ and a working distance of approximately $15 \mathrm{~mm}$. Grain size is defined by an established nomenclature scheme [34], where sand is defined as any grain between $62.5 \mu \mathrm{m}$ and $2000 \mu \mathrm{m}$, coarse mud is between $62.5 \mu \mathrm{m}$ and $32 \mu \mathrm{m}$, medium mud is between $32 \mu \mathrm{m}$ and $8 \mu \mathrm{m}$ and fine mud is anything less than $8 \mu \mathrm{m}$. Samples were categorised based upon their description and combined with the IFPEN lithological log to extrapolate the facies across the entire core.

Total organic carbon contents were measured by a standard LECO combustion procedure at Newcastle University (Newcastle, UK), wavelength-dispersive X-ray fluorescence (XRF) analyses were used to determine elemental concentrations at the Institute for Chemistry and Biology of the Marine Environment (ICBM, University of Oldenburg, Oldenburg, Germany), and stable carbon isotopes values were measured BGS stable isotope facility (part of the National Environmental Isotope Facility) and are calculated to the VPDB standard. Full details reported in Atar et al. (2019a) [14]. 


\section{Results}

\subsection{Facies 1: Clastic Detritus-Rich Medium-Grained Mudstone}

\subsubsection{Description of Facies 1}

The clastic-detritus-rich medium mudstone is composed of a fine mud matrix with medium to coarse grains within it. Most samples are churned to such an extent that any primary textures, e.g., lamination and bedding, are destroyed (Figure 3a,b), but occasional mottling caused by burrowing occurs in some of the thin sections. The matrix is predominantly clay minerals with minor amounts of organic material, occurring as equant "particles", coccolith plates, and scarce pyrite framboids dispersed throughout the matrix (Figure $3 b, c$ ). In addition to the equant organic material, organo-mineral aggregates, comprising of algal macerals and clay minerals, are observed in some samples (Figure 3c-f). The coarsest fraction comprises abundant, unrounded quartz grains, occasional medium mud-sized chlorite grains, fine mud-sized titanium oxide grains, and some samples contain very occasional phosphatic clasts. Pyrite framboids are dispersed throughout the matrix and range between 3-23 $\mu \mathrm{m}$ (Figure 3c-f). Foraminifera are the most commonly occurring fossil within the facies (up to $50 \mu \mathrm{m}$; Figure 3e) and occasional collapsed agglutinated foraminifera are observed. Fragments of disarticulated calcitic shells are commonly observed throughout the facies and typically range between 30-40 $\mu \mathrm{m}$ but are as large as $300 \mu \mathrm{m}$ in length. As is the case with all the observed fossils, the matrix is compacted around the shell fragments. There are several diagenetic features in this facies; intraskeletal pores and some pieces of organic material are infilled with authigenic kaolinite (Figure 3e) or calcite. Pyrite occurs as a replacement mineral in some of the tests of the calcitic foraminifera (Figure 3e) and shell fragments. Very occasional dolomite rhombs are observed in the matrix (Figure 3c) and microcrystalline calcitic strands, approximately $10 \mu \mathrm{m}$ thick and $100 \mu \mathrm{m}$ in length, are aligned to the bedding plane in some samples. Whole-rock geochemical contents of $\mathrm{SiO}_{2}, \mathrm{Al}_{2} \mathrm{O}_{3}, \mathrm{CaCO}_{3}$, and total organic carbon (TOC) along with organic carbon isotopes are presented in Table 1.

Table 1. Ranges of whole-rock geochemical data for each of the identified facies [14]. * Facies 4 only has one carbon isotope datapoint.

\begin{tabular}{ccccccc}
\hline Facies & $n$ & $\mathrm{SiO}_{2}(\mathbf{w t} \%)$ & $\mathrm{Al}_{\mathbf{2}} \mathbf{O}_{3}(\mathbf{w t} \%)$ & $\mathrm{CaCO}_{3}(\mathbf{w t} \%)$ & $\mathrm{TOC}(\mathbf{w t} \%)$ & $\mathbf{1 3}_{\mathbf{o r g}}(\%$ o $\mathbf{~ P D B})$ \\
\hline 1 & 18 & $15.31-45.53$ & $5.81-18.82$ & $7.28-61.56$ & $1.86-20.01$ & $-27.89--25.16$ \\
\hline 2 & 9 & $7.14-40.80$ & $2.62-17.99$ & $15.81-66.56$ & $5.61-19.53$ & $-26.75--22.93$ \\
\hline 3 & 4 & $20.79-40.66$ & $9.02-17.77$ & $12.85-51.37$ & $5.69-11.70$ & $-27.42--24.67$ \\
\hline 4 & 2 & $29.20-40.40$ & $12.06-15.95$ & $20.75-28.24$ & $3.78-13.05$ & $-25.15 *$ \\
\hline 5 & 2 & $42.29-42.31$ & $16.20-16.50$ & $13.26-14.34$ & $13.26-5.64$ & $-27.19-26.28$ \\
\hline 6 & 3 & $13.01-17.69$ & $5.87-7.23$ & $65.11-73.75$ & $0.78-1.28$ & $-27.08--26.83$ \\
\hline \multicolumn{7}{c}{ VPDB = Vienna Pee Dee Belemnite standard reference material. }
\end{tabular}



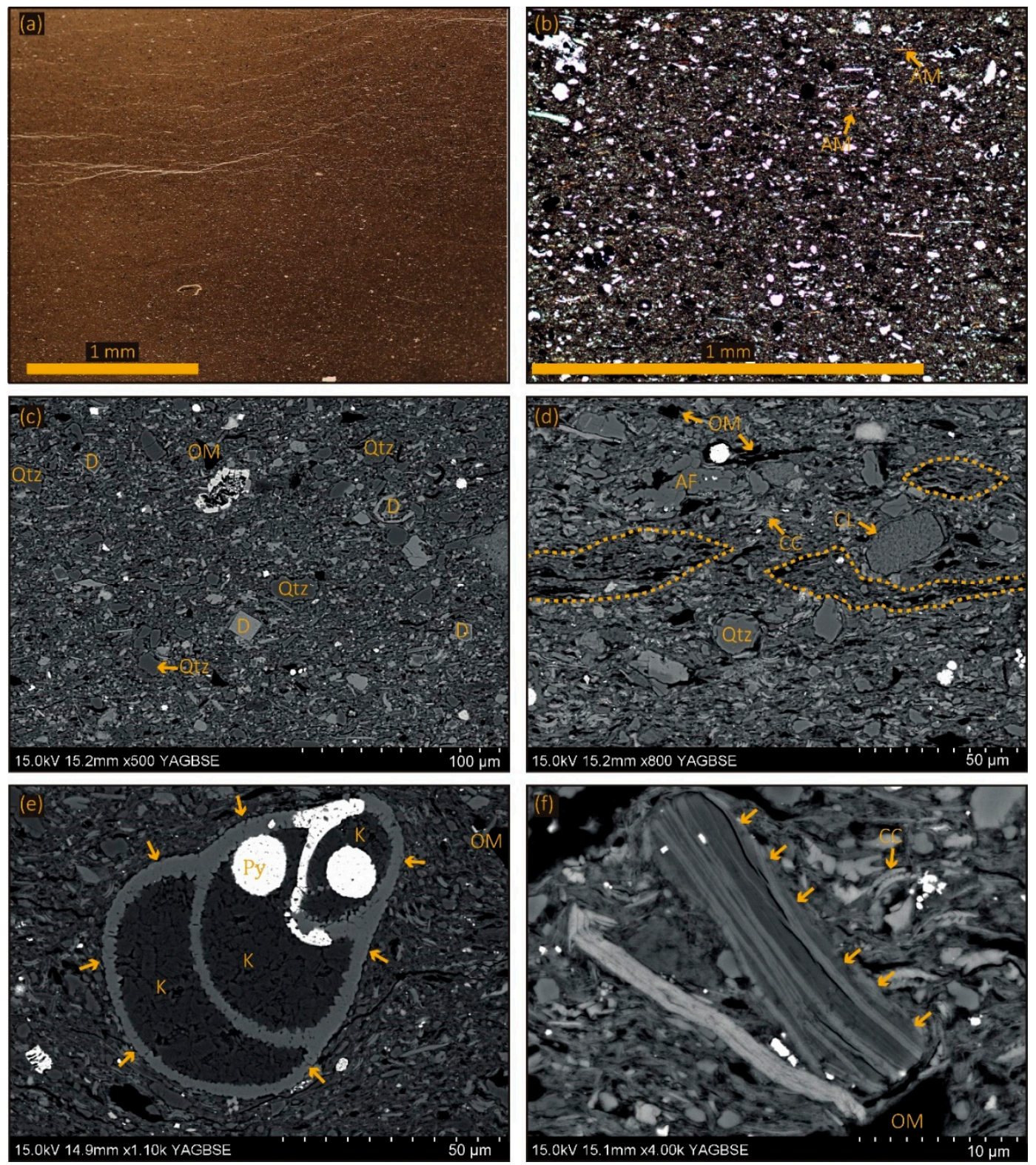

Figure 3. Facies 1: Clastic-detritus-rich medium-grained mudstone. (a) Low power optical photomicrograph of EB $33.17 \mathrm{~m}$ showing the homogenous nature of the facies. (b) Optical micrograph of sample EB $33.17 \mathrm{~m}$ showing homogeneous nature of the sample. Note the presence of algal macerals (AM) and the argillaceous matrix. (c) Backscattered electron photomicrograph of sample EB $57.70 \mathrm{~m}$. Note the dolomite rhombs (D) and equant organic material (OM). (d) Backscattered electron photomicrograph of sample EB $64.50 \mathrm{~m}$. Yellow dashed lines mark the boundary of organo-minerallic aggregates. Note the presence of single collapsed agglutinated foraminifera (AF), clay mineral grain (CL) and coccolith debris (CC) in the matrix. (e) Backscattered electron photomicrograph of sample EB $35.17 \mathrm{~m}$ showing a multi-chambered foraminifera (yellow arrows) infilled with authigenic kaolinite (K). Note the presence of pyrite (high $\eta$ ) as framboids and as a replacement mineral in the foraminifera test. (f) Backscattered electron photomicrograph of sample EB $35.17 \mathrm{~m}$ showing a chlorite grain (indicated by the yellow arrows).

\subsubsection{Interpretation of Facies 1}

The dominant sedimentary components are detrital grains, i.e., clay minerals, quartz grains and lithic clasts, indicating that this facies was deposited in a system that received a regular supply 
of terrigenous material. This is further supported by the ubiquitous presence of titanium oxide which is likely to reside in the resistant refractory mineral rutile. In contrast to wispy lamina algal-derived organic matter, equant pieces of organic material are characteristic of Type III terrigenous organic material, this is supported by the organic carbon isotope data (Table 1). Whether or not this facies was reworked prior to being deposited is impossible to tell given the homogenous nature of the sediment. Churning of the sediment likely resulted from a combination of physical mixing processes-i.e., sediment transport as a result of bottom currents as suggested from erosional bases, and bioturbation as demonstrated by the presence of burrows.

Extensive bioturbation has been interpreted to indicate a well-oxygenated water column that allowed burrowing fauna to colonise the sediment surface at least intermittently [68], it is impossible to determine whether or not the colonization of the sediment was prolonged or whether it occurred in pulses. However, recent work shows that bioturbation may not be the best indicator of bottom water oxygenation [69]. The low abundance of algal macerals, characteristic of marine Type II organic matter, in the matrix is supporting evidence for an oxygenated water column, as algal macerals are easily destroyed through oxidation [9]. At least episodic bottom water/seafloor oxygenation is evidenced by the presence of agglutinated foraminifera. Total organic carbon contents range between 1.98 to 20.01 wt \% (Table 1) [14], suggesting sediment-pore waters were sufficiently oxygen-depleted to inhibit extensive oxidative degradation of OM. Trace element geochemical data suggest a suboxic sediment-water interface [14], thus supporting the petrographic evidence for oxygen depletion. However, the presence of organo-mineral aggregates offers a plausible explanation for the delivery of algal maceral material to the seafloor. Physical and chemical attractions between the aggregate components may have formed a protective barrier to oxidative destruction of the algal macerals and facilitated their preservation [10]. The presence of both algal macerals in organo-mineral aggregates and type III organic matter in the matrix explains the range of ${ }^{13} \mathrm{C}_{\text {org }}$ values of this facies.

The sparse occurrence (relative to the other facies) of calcitic fossils and algal maceral-bearing organo-mineral aggregates suggests that primary productivity was low to moderate at the time of deposition and that there was a vertical sediment supply in addition to the longer-distance lateral supply inferred by the terrigenous material. The large range in $\mathrm{CaCO}_{3}$ (Table 1) is likely accounted for by carbonate cements in some of the samples. $\mathrm{CaCO}_{3}$ occurs in these samples in primary and secondary forms so the value in using petrographic information to contextualise geochemical data is highlighted here. In addition to low to moderate productivity levels, the absence of algal macerals in the matrix may also point towards unfavourable organic material preservation conditions. The low algal maceral content in the matrix is likely to result from a combination of both low productivity and poor preservation.

\subsection{Facies 2: Organic Material and Calcareous Pellet-Rich, Laminated Mudstone}

\subsubsection{Description of Facies 2}

Discontinuous wavy laminae in this facies are organised into $10 \mathrm{~cm}$-thick, normally graded beds with erosional bases (Figure 4a). Some samples exhibit compositional alternations, every $5 \mathrm{~mm}$ (Figure $4 \mathrm{~b}, \mathrm{c}$ ), between clay-rich and carbonate-rich lithologies. The major sedimentary components of this facies are organic material, clay minerals, quartz, and calcareous biogenic material (e.g., coccolith plates and foraminifera; Figure $4 \mathrm{a}-\mathrm{f}$ ); medium to coarse grains and pellets exist within a fine mud matrix (Figure 4e,f). A facies-defining feature is the high abundance of algal maceral material $(30 \%)$. It appears orange and wispy under plain polarised light and wraps around other sedimentary components (Figure 4c). Commonly, the algal maceral material occurs as organo-mineral aggregates (Figure 4e,f). Additionally, equant pieces of organic material float within the matrix (Figure $4 \mathrm{c}-\mathrm{f}$ ). Medium to coarse quartz grains, coarse lithic clasts comprising clay and fine quartz, and calcareous nannofossil tests float within the organic matter-rich argillaceous matrix (Figure $4 \mathrm{~d}-\mathrm{f}$ ). The nannofossil tests are generally still intact and filled with either authigenic calcite or kaolinite 
(Figure 4e). Coccolith material is generally organised into pellets (ca. $60 \mu \mathrm{m}$ ) but also floats in the matrix. Some of the pellets comprise finer, disarticulated coccolith material and others contain pristinely preserved coccolith plates and coccospheres (Figure 4e,f). Framboidal pyrite (generally less than $10 \mu \mathrm{m}$ ) is abundant throughout the facies and pyrite is also present as euhedral crystals and as a replacement mineral. Whole-rock geochemical contents of $\mathrm{SiO}_{2}, \mathrm{Al}_{2} \mathrm{O}_{3}, \mathrm{CaCO}_{3}$, and TOC along with organic carbon isotopes are presented in Table 1 [14].
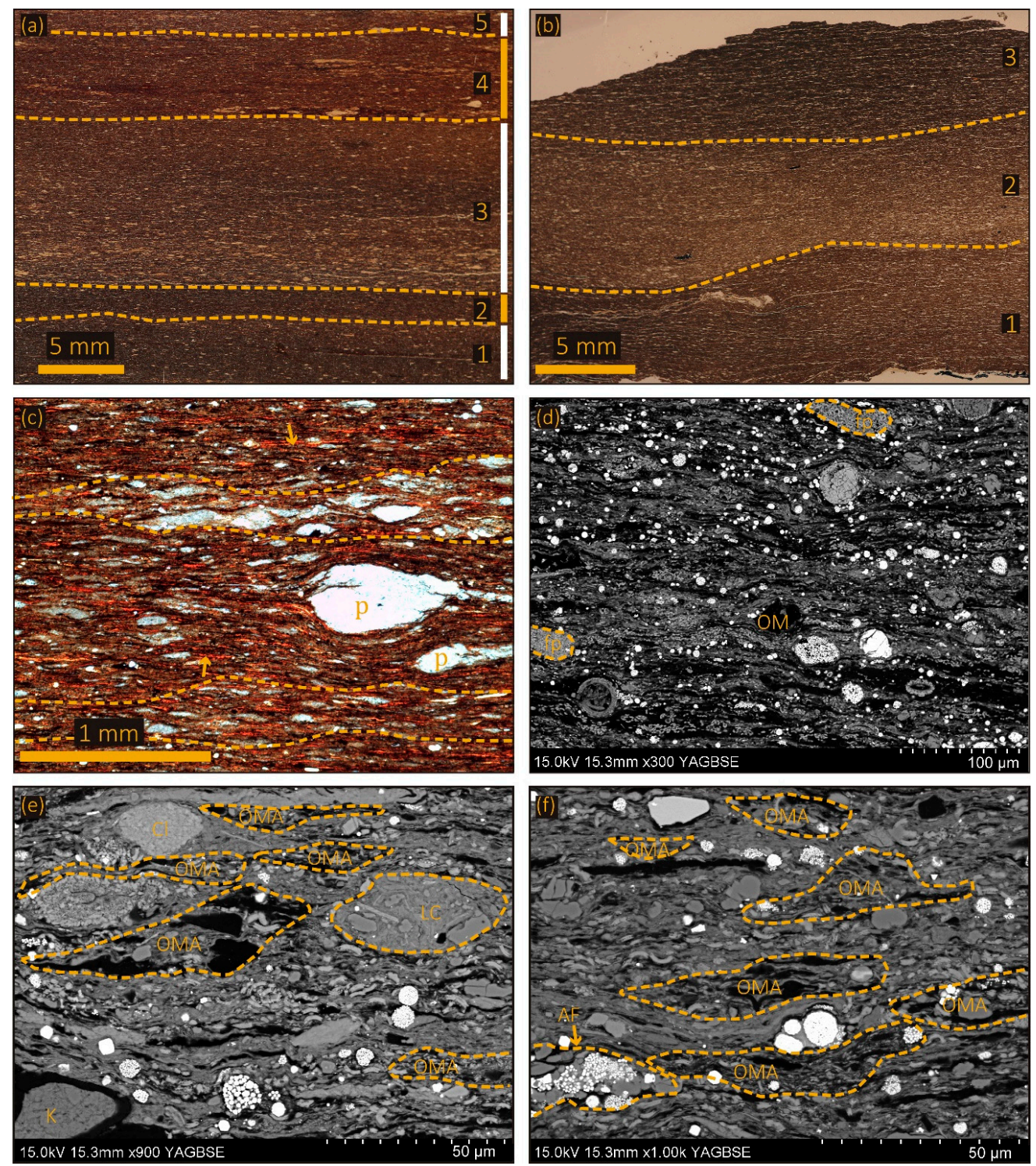

Figure 4. Facies 2: Organic material and calcareous pellet-rich, laminated mudstone. (a) Low powered optical micrograph of sample EB $46.50 \mathrm{~m}$ showing normally graded beds that have erosional bases (a to d). (b) Low powered optical micrograph of sample EB $45.50 \mathrm{~m}$ showing apparent compositional banding between the lamina. Brighter laminae are carbonate-rich and the darker laminate are more clay-rich (c) Optical micrograph of sample EB $46.50 \mathrm{~m}$. Note the apparent compositional banding between the lamina (outlined by yellow dashed lines). Calcareous faecal pellets are labelled as $\mathrm{p}$ and red algal macerals are marked by yellow arrows. (d) Backscattered electron photomicrograph of sample EB $36.92 \mathrm{~m}$. Calcareous faecal pellets (fp) and equant organic material (OM) float in a clay and organic rich matrix. Pyrite is present as framboids, microcrystals and as a replacement mineral (high $\eta$ ). (e,f) Backscattered electron photomicrographs of sample EB $46.50 \mathrm{~m}$. Lithic clasts (LC), organo-mineral aggregates (OMA) and clay aggregates $(\mathrm{Cl})$, and agglutinated foraminifer (AF) sit within a clay and coccolith-rich matrix. Authigenic kaolinite $(\mathrm{K})$ infills some of the organic matter. 


\subsubsection{Interpretation of Facies 2}

This facies is interpreted to represent the highest level of primary productivity due to the high abundance of algal macerals and coccolith plates. The discontinuous, wavy laminar structure within this facies may be explained through the deposition of organic material as algal mat structures and their subsequent disruption through modest bioturbation. Alternatively, it may represent the compaction of discrete aggregates. Normally-graded beds with erosional bases are interpreted to represent local reworking of the sediment. A recent study attributes storm activity as a key mechanism for the concentration of sulphurised organic material in Tithonian deposits in Boulonnais (France) [70]. The authors propose that an abundance of pyrite, commonly associated with sulphurised organic material, may alter the hydrodynamic behaviour of the sediment, which may promote the concentration of organic material, and that the organic material is likely to be more resistant to oxidative destruction owing to its sulphurisation. The normally graded beds with erosional bases may be tempestites that mobilized sediment from shallow to slightly deeper settings during storms. Storm conditions would have stirred up the ocean ensuring a plentiful supply of oxygen and nutrients to the photic zone, promoting primary productivity during these times.

The calcareous pellets are interpreted to be faecal pellets. The shape, size and composition of the pellets suggest that they were produced by zooplankton that selectively fed upon coccolith material [9]. The common occurrence of quartz grains, clay minerals and terrestrial organic material indicates that the studied part of the Cleveland Basin received detrital material during the deposition of this facies. Compositional alternations between clay- and carbonate-dominated beds may reflect variations between sediment supply and primary productivity, infrequent additions of terrigenous material, intermittent storm conditions, or a combination of the above. Compositional alternations are reflected by the large ranges in whole-rock geochemical characterisation for this facies (Table 1).

\subsection{Facies 3: Coccolith-Dominated Medium Mudstone}

\subsubsection{Description of Facies 3}

This facies is organised into normally-graded laminae that have erosional bases (Figure 5a). The main sedimentary components are coccolith material, clay minerals, and organic matter (Figure 5a-f). The matrix mainly comprises pristinely preserved coccolith plates and coccospheres (Figure 5e), as well as clay minerals, equant pieces of organic material and wispy algal macerals, calcispheres (Figure 5d), chlorite grains, coarse sub-rounded quartz grains (Figure 5e), pyrite framboids, and euhedral pyrite crystals (Figure 5f). Although coccoliths are ubiquitous in the matrix, they are also arranged into pellets (Figure $5 \mathrm{c}, \mathrm{d}, \mathrm{f}$ ). The pellets range in size from 10-200 $\mu \mathrm{m}$ and fall into three distinct groups based on composition. The most commonly occurring pellets comprise solely very fine, disarticulated coccolith plates (Figure 5e). The remaining two groups occur much more occasionally; one comprises coccolith plates and coccospheres and the other exhibits a sparry, calcitic texture. Compacted calcareous microfossils are present throughout this facies, along with agglutinated foraminifera and rare undifferentiated shell fragments (Figure $5 a, b$ ). Whole-rock geochemical contents of $\mathrm{SiO}_{2}, \mathrm{Al}_{2} \mathrm{O}_{3}, \mathrm{CaCO}_{3}$, and TOC along with organic carbon isotopes are presented in Table 1 . 

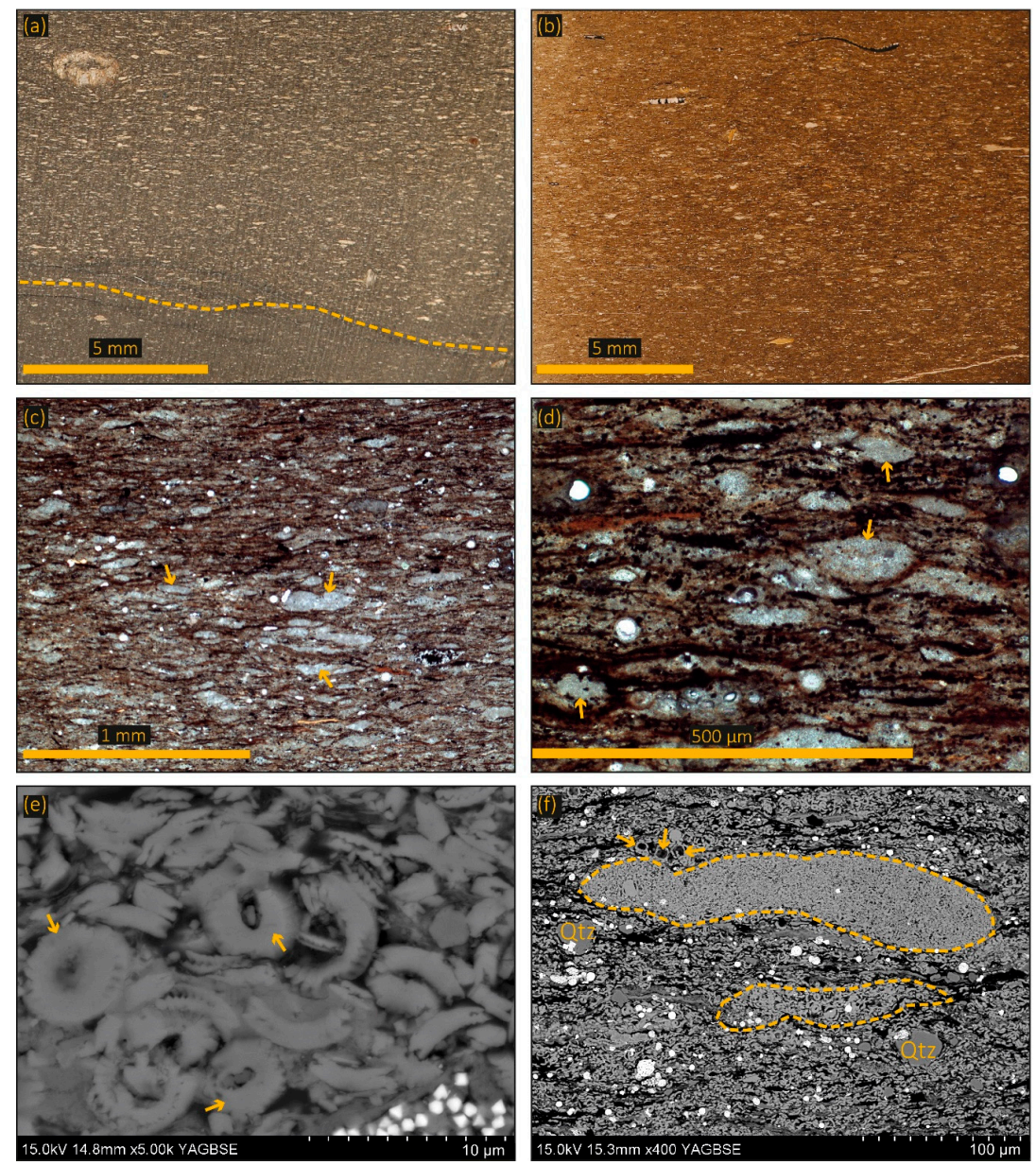

Figure 5. Facies 3: Coccolith-dominated medium mudstone. Sample EB $39.00 \mathrm{~m}$. (a) Low power optical micrograph of a slab. Yellow dashed line shows erosional base. (b) Low power optical micrograph of a polished thin section. (c) Optical micrograph showing the calcareous pellet-rich (yellow arrows) nature of this sample. (d) Optical micrograph showing calcareous pellets in an argillaceous and carbonaceous matrix. Note the presence of organic macerals (red horizontal lines) and calcispheres (circled in yellow). (e) Backscattered electron photomicrographs showing coccolith plates (yellow arrows). (f) Backscattered electron photomicrograph showing the coccolith rich nature of the pellets (dashed yellow lines) and surrounding matrix. Note the presence of quartz grains (Qtz), organic material (OM), and pyrite framboids (py) and the exceptional preservation of coccospheres (yellow arrows in (f)).

\subsubsection{Interpretation of Facies 3}

The presence of detrital quartz and clay, along with terrestrial organic material, indicates a continued terrigenous supply of sediment. The gradational nature of the beds along with their erosional bases suggests sediment has been reworked. The dominance of coccolith material coupled with the preservation of organic material suggests this facies was deposited under a highly productive water column. The coccolith-rich faecal pellets are likely to be the product of selectively feeding zooplankton in the water column, indicating the photic zone was oxygenated $[9,10]$. Modelling and experimental investigation has demonstrated that export of carbon and sediment flux to the seafloor is significantly greater when it is facilitated by scavenging zooplankton owing to the larger grain size and denser nature of faecal pellets [71]. The presence of foraminifera supports the interpretation that this facies was deposited during a time of higher primary productivity. The calcispheres have unknown origins but may be remnants of dinoflagellates, again pointing towards a productive water column. 


\subsection{Facies 4: Agglutinated Foraminifera-Bearing, Medium to Coarse, Carbonaceous Mudstone}

\subsubsection{Description of Facies 4}

This facies is heavily churned but relict lamination is observed in one sample. It comprises an argillaceous, calcareous, and carbonaceous matrix with medium to coarse grains within a fine mud matrix (Figure 6a-f). Coarse grains are predominantly composed of agglutinated foraminifera, lithic clasts (possibly mud clasts), algal macerals, and clay and quartz grains (Figure 6c). Agglutinated foraminifera are comprised of quartz grains, coccolith debris, and clay minerals, and some of them have post-depositional replacement by framboidal pyrite (Figure $6 \mathrm{~d}, \mathrm{e}$ ). Organic material is present as algal macerals and equant pieces in both the matrix and in organo-mineral aggregates (Figure $6 \mathrm{~b}-\mathrm{f}$ ). Occasional coccolith-rich pellets are observed floating in the matrix. Whole-rock geochemical contents of $\mathrm{SiO}_{2}, \mathrm{Al}_{2} \mathrm{O}_{3}, \mathrm{CaCO}_{3}$, and TOC along with organic carbon isotopes are presented in Table 1.
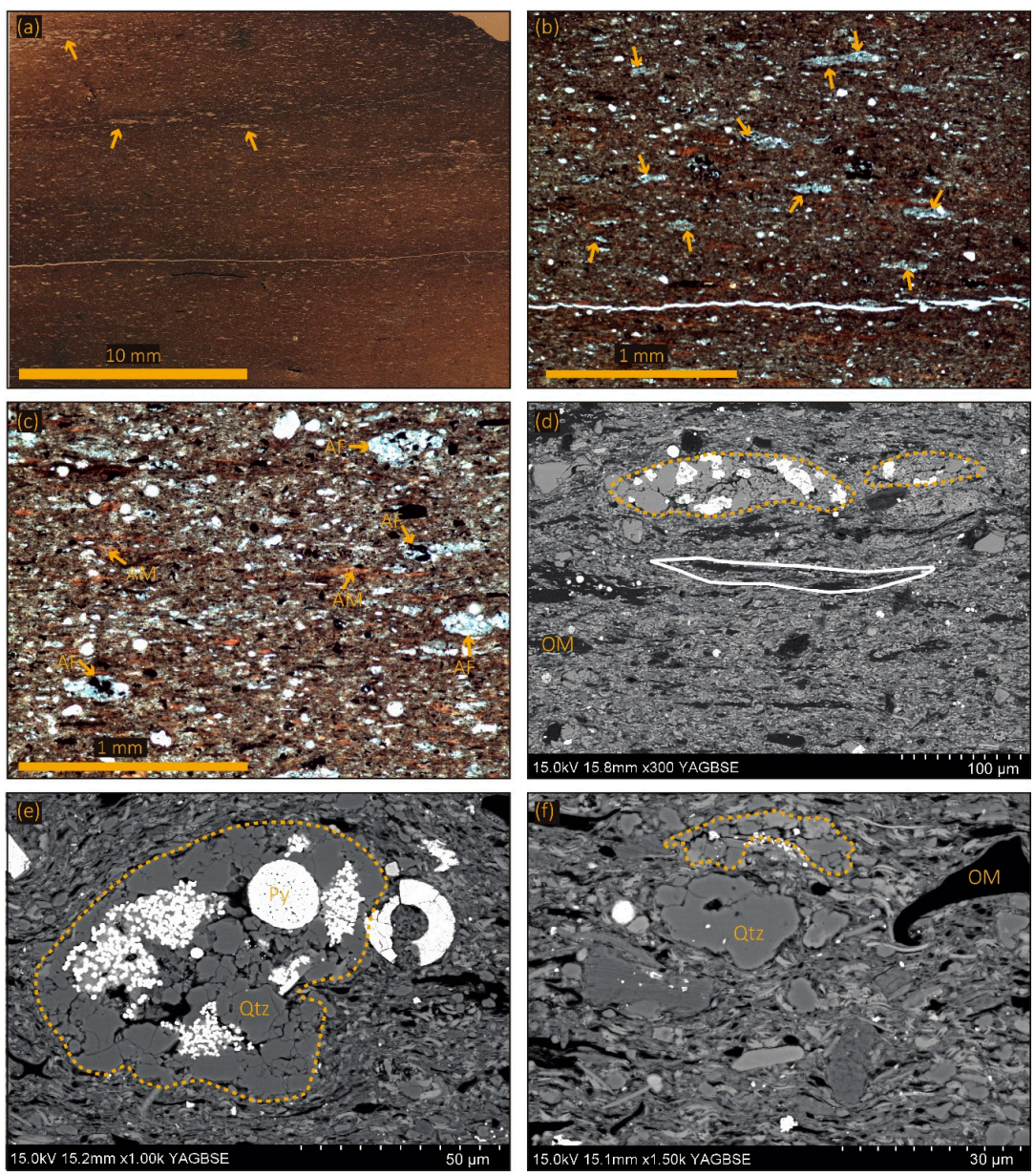

Figure 6. Facies 4: Agglutinated foraminifera bearing, medium to coarse, carbonaceous mudstone. Sample EB $46.60 \mathrm{~m}$. (a) Low power optical micrograph of a thin section. Yellow arrows point to collapsed agglutinated foraminifera. (b) Optical micrograph. Yellow arrows indicate abundant agglutinated foraminifera. (c) Optical micrograph showing agglutinated foraminifera (AF) amongst algal macerals (AM). (d) Backscattered electron photomicrographs showing amorphous organic material (AOM), agglutinated foraminifera (yellow dashed line), and organo-mineralic aggregate (white dotted line) in an argillaceous matrix. (e) Backscattered electron photomicrographs showing an agglutinated foraminifera (dashed yellow lines) comprising quartz, pyrite, and surrounding matrix, reprinted with permission from Atar et al. (2019a) [14]. (f) Backscattered electron photomicrographs quartz (e.g., Qtz), clay grains, organic material (OM), agglutinated foraminifera (yellow dashed line) in an argillaceous matrix. 


\subsubsection{Interpretation of Facies 4}

During the deposition of this facies, the Cleveland Basin received material from a terrigenous source as indicated by the presence of detrital clays, quartz, lithic clasts, and equant pieces of organic matter, which is reflected in the whole-rock geochemical data (Table 1). Churning of the sediment is likely due to a combination of bioturbation and physical mixing processes and relict lamination points towards sediment mobilization. The high abundance of benthic agglutinated foraminifera indicates the presence of oxygen at the sediment-water interface. However, the carbonaceous nature of the matrix implies at least periodic sediment pore water anoxia. This facies represents a period of time when the Cleveland Basin experienced constantly fluctuating redox conditions and a combination of autochthonous and allochthonous sediment supply.

\subsection{Facies 5: Biogenic Detritus-Dominated, Fine to Medium Mudstone}

\subsubsection{Description of Facies 5}

This facies comprises a quartz-rich, argillaceous matrix with medium mud- to sand-sized quartz and clay mineral grains, e.g., chlorite, calcitic rhombs, foraminifera shells, equant pieces of organic material and framboidal pyrite (up to $10 \mu \mathrm{m}$; Figure 7a-f). Disarticulated calcitic shells dominate this facies (Figure 7a,c,f); they are wholly or partially replaced by pyrite (Figure 7f). Locally, a network of discontinuous calcareous structures overprints this facies; the network "filaments" are generally sub-parallel to the bedding and have a calcitic composition (Figure 7a,b). Whole-rock geochemical contents of $\mathrm{SiO}_{2}, \mathrm{Al}_{2} \mathrm{O}_{3}, \mathrm{CaCO}_{3}$, and TOC along with organic carbon isotopes are presented in Table 1 .

\subsubsection{Interpretation of Facies 5}

This facies is interpreted to represent a time when depositional energy was relatively high. The shell fragments were likely transported to the site of deposition by storm and/or current activity and disarticulated in the process. There is a moderate diagenetic overprint to this facies, evidenced by partial replacement of shells by pyrite, and it is likely that the carbonate veining formed due to the partial dissolution of the shells and re-precipitation along sedimentary planes or weaknesses. 

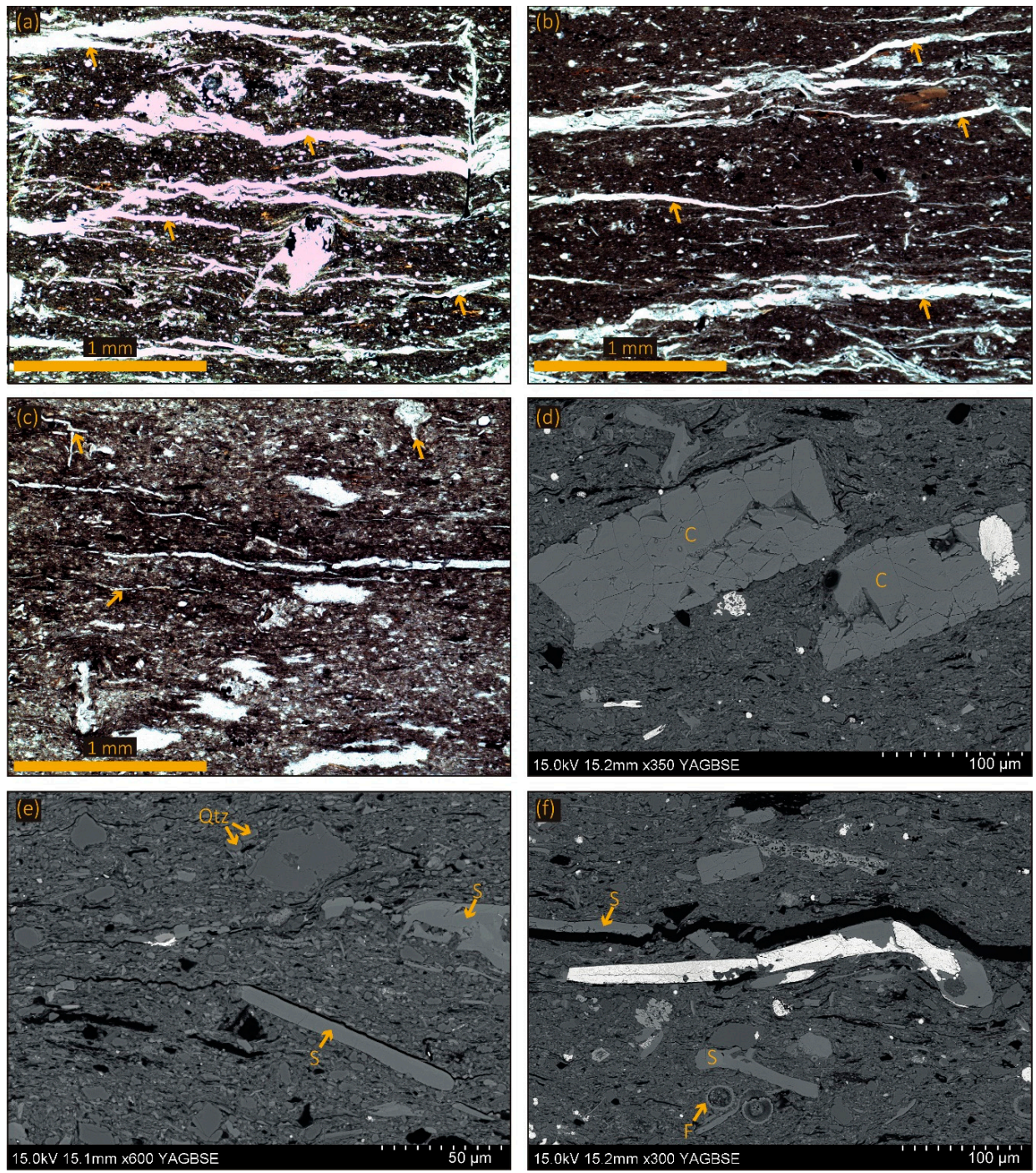

Figure 7. Facies 5: Biogenic detritus dominated, fine to medium mudstone. Sample EB $71.00 \mathrm{~m}$. $(\mathbf{a}-\mathbf{c})$ Optical photomicrographs showing a network of discontinuous calcareous structures (pointed to by the yellow arrows) through an argillaceous matrix. (d) Backscattered electron photomicrograph showing calcareous rhombs that have been partially replaced by pyrite. (e) Backscattered electron photomicrograph showing calcareous shell fragments (S) and abundant quartz grains (Qtz) in an argillaceous matrix. (f) Backscattered electron photomicrograph showing a calcitic shell that has been partially replaced by pyrite. Note the presence of well-preserved foraminifera tests $(F)$.

\subsection{Facies 6: Carbonate-Cemented, Fine to Medium Mudstone}

\subsubsection{Description of Facies 6}

In hand specimen, this facies is yellow to white and hard. Optical light petrography shows this is a medium to coarse, angular, diagenetic carbonate-dominated sediment with an argillaceous matrix (Figure 8a,b). Scanning electron microscopy shows that the carbonate is microcrystalline, zoned non-ferroan calcite and non-ferroan dolomite crystals (Figure 8c-f). Relict matrix, comprising coccolith debris, illitic clay and fine quartz grains, can be seen between the diagenetic components (Figure $8 \mathrm{c}-\mathrm{f}$ ). Minor pyrite is present as small $(>10 \mu \mathrm{m})$ framboids throughout the matrix and within carbonate crystals (Figure $8 \mathrm{c}-\mathrm{f}$ ). Whole-rock geochemical contents of $\mathrm{SiO}_{2}, \mathrm{Al}_{2} \mathrm{O}_{3}, \mathrm{CaCO}_{3}$, and TOC along with organic carbon isotopes are presented in Table 1. 

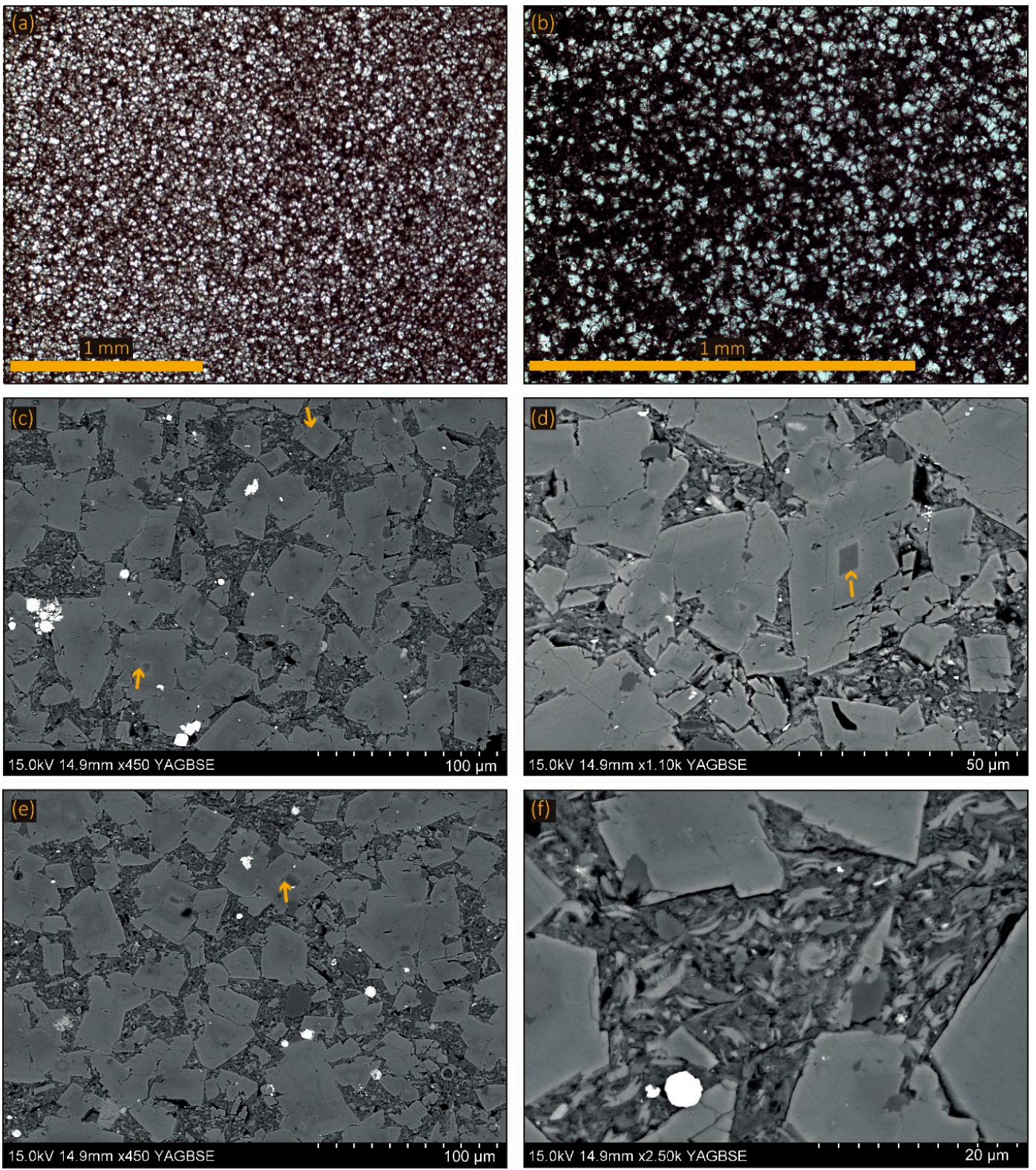

Figure 8. Facies 6: Carbonate cemented, fine to medium mudstone composed of calcium and magnesium carbonate (dolomite) crystals in a clay-rich matrix $(\mathbf{a}, \mathbf{b})$ Optical micrographs of carbonate cemented, coarse grained mudstone. (c-f) Backscattered electron photomicrographs. Yellow arrows point to zonation within dolomite crystals. Note the relict matrix composed of clay minerals and coccolith debris. Note the presence of pyrite (bright white components) within both the matrix and crystals.

\subsubsection{Interpretation of Facies 6}

The dolomites in this facies are interpreted as early diagenetic precipitates given their textbook rhombohedral shape, with formation at low temperature (ca. $23-30{ }^{\circ} \mathrm{C}$ [72]). Dolomite is a calcium-magnesium carbonate that precipitates from $\mathrm{Mg}$ - and Ca-rich waters. The easiest way for this to occur is the concentration of magnesium in sea water, either through increased discharge of meteoric water into a marine setting, or through restriction of an oceanic setting leading to net evaporation of the water column. However, both mechanisms are difficult to reconcile in the present setting due to an absence of sedimentological evidence for enhanced fluvial input or marine restriction [14]. A third mechanism put forward for the Yorkshire section [5] and for the coeval Dorset section [72] involving microbial mediation of dolomite precipitation is possible. Microbial 
mediation of dolomite formation through increased alkalinity and $\mathrm{pH}$ associated with bacterial sulphate reduction may overcome the kinetic barrier to dolomite precipitation. Furthermore, the removal of sulphate from sediment pore waters provides a source of magnesium once liberated from magnesium sulphate ions. Thus, sulphate reducing bacteria create the required conditions for the precipitation of calcium magnesium dolomite $[73,74]$ and may have been facilitated by pauses in sediment supply to the depocenter.

Alternatively, the dolomites may have formed in sulphate-methane transition zones beneath the seafloor. The required methane may be sourced through degradation of underlying organic material and the sediment surface needed to be in a steady state, which may have been facilitated by pauses in sedimentation. This facies is ignored in the context of palaeoenvironmental discussion because the main component, authigenic dolomite, is not a primary depositional feature.

\section{Discussion}

\subsection{Sedimentary Components and Sediment Supply}

Petrographic inspection of the studied succession demonstrates that it is made up of variable proportions of detrital clay minerals, quartz, lithic clasts, organic material (OM), biogenic components and authigenic minerals, which agrees with the initial studies on the core [5,59]. The compositional differences, along with sedimentary textures and bedding characteristics, have been used to divide the section into six facies. Although gradational transitions exist between the facies, they can be grouped into those that predominantly comprise detrital material, those that comprise biogenic material, and the single one that is overprinted by diagenetic carbonate. The temporal distribution of the facies is such that most of the section comprises bioturbated, detrital sediment (Facies 1 and 5) that is punctuated by sediment dominated by carbonate and organic material (Facies 2, 3, and 4).

The most common facies amongst the thin sections are Facies 1 and 5 (Figure 2). Clay minerals constitute most of the matrix in Facies 1 and 5 (Figure 3). Although authigenic kaolinite is precipitated in some of the foraminifera tests (Figure 3f), the clay mineral matrix appears to be allogenic. Geochemical analysis shows that the clay mineral assemblages in the Cleveland and Wessex Basins are similar; kaolinite and illite are the main minerals in both basins $[5,13,75]$. The clay minerals are likely to be the product of weathering and erosion of sub-aerially exposed siliciclastic rocks on the adjacent hinterland [76]. Clay minerals also occur within lithic clasts (Figure 5e), which are likely ripped up from the seafloor and redeposited. However, it is not possible to discern what route the matrix clay minerals took, whether it was directly from the hinterland to the depocenter or whether it is palimpsest in nature, meaning it is relict sediment delivered to the setting long before deposition [77]; the sediment dispersal mechanisms (discussed below) may give further insight into this.

The other detrital minerals-e.g., rutile and feldspars-are also likely to be derived from the adjacent hinterland and thus entered the Cleveland Basin through a fluvial or aeolian source. However, an aeolian source is difficult to reconcile in a time where sea levels were high and much of the continent was submerged under water given the inevitable reduction in the spatial extent of deserts [78]. Also, petrographic evidence of sub-angular and poorly sorted grains (Figure 3c,d) does not support an aeolian source. Volcanic ash is ruled out as a source of quartz in the studied succession due to the absence of fragmented volcanic rock, glass, and minerals observed in thin section. Therefore, riverine input is also the most likely source of detrital quartz in the Cleveland Basin.

Organic matter is derived from both marine and terrestrial sources. Carbon isotopes demonstrate the occurrence of both marine Type II and terrestrial Type III OM in the studied section, where Type III $\mathrm{OM}$ (characterised by heavier carbon isotope values) is mainly associated with Facies 1, 3, 5, and 6 and Type II OM (characterised by lighter carbon isotope values) is mainly associated with Facies 2 and 4 [14]. Type III OM occurs as equant pieces throughout the section and was likely washed into the Cleveland Basin through the same sediment routing system as the detrital minerals. The presence of Type III OM accounts for background levels of $2-5 \mathrm{wt} \%$ total organic carbon (TOC; [14]) in much of 
the section. Conversely, the Type II OM is present as algal macerals (Figure 4), which were produced in the water column at times of high primary productivity.

The carbonate constituents of the sediment are predominantly calcareous fossils and are marine in origin. Pristine coccolith plates make up the largest volume of fossils (Figure 5e,f); coccolithophorid blooms are likely the source of this component, suggesting deposition occurred under a highly productive water column at least intermittently throughout the studied interval. Prolific production of coccolith-rich faecal pellets, relative to the other facies, also suggests a highly productive water column with an active zooplankton community. For most of the section, $\mathrm{CaCO}_{3}$ contents are 5-10 wt \% [14], and petrography demonstrates this is mainly coccolith material; microfossils were frequently supplied to the sediment and possibly reworked. Fossil tests, foraminifera, and macroscopic shell fragments also occur throughout the section, albeit in much smaller quantities.

Elevated primary productivity and high fluxes of biogenic components are likely to aid in the preservation of OM. In order to be preserved, OM needs to be removed from interaction with oxidants so that oxidative destruction of the $\mathrm{OM}$ is minimized [27,79-81]. This is facilitated in epicontinental seaways where the sediment pore waters and sediment-water interface are likely depleted in oxygen due to high productivity in the surface waters, and where the path from primary production to the seabed is short owing to shallow water depths. Therefore, high primary productivity rates, as evidenced by an abundance of biogenic sedimentary components, likely facilitated the preservation of $\mathrm{OM}$ in the Cleveland Basin during the Late Jurassic. This is supported by trace element geochemistry that indicates sediment pore waters, and perhaps bottom waters, were suboxic to euxinic during the deposition of most of the studied interval, the exception being fully oxygenated conditions during the deposition of Facies 2 [14]. Storm activity, suggested by normally graded beds with erosional bases, also may have acted to concentrate organic matter in Facies 2 through the alteration of hydrodynamic properties of the sediment [70].

The calcareous diagenetic components in the studied section-i.e., the dolomite rhombs in Facies 6 and 1, the calcite "stringer" in Facies 5, and the calcite-filled tests-likely result from local dissolution and reprecipitation of carbonate minerals. Oxidation of organic matter produces $\mathrm{CO}_{2}$ which can dissolve carbonate minerals which can then reprecipitate in a more stable form under the optimal conditions; i.e., dolomite precipitation may occur during pauses in sedimentation and result from calcite dissolution. Similarly, the authigenic clay minerals are likely to result from local dissolution and reprecipitation of semi-amorphous $\mathrm{Al}$ hydroxide phases that were the product of tropical weathering on the adjacent hinterland.

Variation in the proportions of each sedimentary component demonstrates that the sediment supply varied through time. The time-equivalent sediments in the Wessex Basin comprised of the same sedimentary components; detrital minerals, marine OM, carbonate, and diagenetic constituents [10]. Detrital material likely entered the Wessex Basin through rivers, and that the facies rich in calcareous nannofossils and marine OM were deposited under a highly productive water column [10], similar to that described for the Cleveland Basin. Climate model simulations suggest that the Cleveland and Wessex Basins were under the influence of tropical conditions during the Late Jurassic [14,15,23]. Overarching climatic conditions as primary control on sedimentation in these basins can explain the apparent similarities between the two sections and throughout NW Europe [65].

\subsection{Sediment Dispersal Mechanisms and Sedimentation Rates}

Epicontinental seaways are often on the order of $1000 \mathrm{~km}$ wide and rarely exceed $10 \mathrm{~s}$ of metres of water depth, leading to extremely gentle "shelf slopes" of around $0.01^{\circ}$ [78]. Given such a setting, it is not unreasonable to infer that detrital minerals, which constitute the majority of the studied section (Facies 1; Figure 2), entered the basin through riverine input and were then transported by wind-driven Coriolis forces and Ekman transport-influenced bottom currents [78]. In the modern day, fluvial systems are the dominant source of mud to the ocean [82]; observations of shelf environments have demonstrated distinctly higher sediment remobilisation and transport that is promoted by bottom 
currents and enhanced wave-current interactions associated with storm activity [83]. In ancient environments, these processes would have driven physical mixing of the sediment which may have formed a homogenous sedimentary texture, as described in Facies 1 (Figure 3a).

Bioturbation that resulted from the colonisation of sediment by burrowing organisms will have also churned the sediment (Figure 3a,b). This had an effect on the preservation of authochthonous organic material as it irrigated the surface sediments with oxygen; however, allochthonous (terrigenous) organic material was likely most resistant to oxidative degradation, thus total organic carbon contents greater than $2 \mathrm{wt} \%$ throughout most of the section (Facies 1 and 5) can be explained by its presence.

Normally graded beds with erosional bases, observed in Facies 2, probably represent tempestites (Figure $4 \mathrm{a}, \mathrm{b}$ ), when storm-driven sediment suspension led to traction transport and subsequent suspension settling [10]. Higher energy conditions are also inferred for similar facies in the KCF in the Wessex Basin $[10,15]$ and may be responsible for concentrating sulphurised OM by hydrodynamic sorting as suggested for other Late Jurassic deposits [70].

In Facies 2 and 4, algal macerals occur in two forms: algal mats (Figure 4c) and organo-mineral aggregates (Figure 4e,f). Algal mats form filamentous structures that align to the direction of bedding during compaction (Figure 4c). The structure of an algal mat, possibly formed at the oxic-anoxic interface in the water column, allows for the development of anoxic pockets, which can facilitate the preservation of OM [9]. Organo-mineral aggregates form through a combination of planktonic mucus secretions acting as glue, electrochemical attractions, and physical interlocking of individual grains [9]. Once in an organo-mineral aggregate, preservation potential of the OM is increased because settling velocity increases, so the OM is removed from oxygenated conditions more quickly, which was a contributing factor to the exceptionally high (>20 wt \%) TOC values in Facies 2 and 4.

In a similar way to the organo-mineral aggregates, the incorporation of coccolith plates into faecal pellets (Figures $4 c$ and $5 c, d, f$ ) increased their preservation potential due to increased settling velocity. Pelleted material would have a much quicker sedimentation rate than the individual components; this has been demonstrated in lab experiments where phytoplankton organised into pellets falls through the water column at five times the rate than individual components [84]. Given the epicontinental setting, where water depth exceeded no more than a couple of hundred metres, it is likely that pellets took less than day to reach the seafloor.

Given the diverse and dynamic sediment dispersal mechanisms in the Cleveland Basin, particularly the abundant presence of pellets, it is likely that the sedimentation rate through this succession was very variable. Therefore, we conclude that linear sedimentation rates, calculated from ammonite biozones, cannot be extrapolated and must carry large uncertainty due to unequivocal discontinuous sedimentation evidenced by sedimentological structures. Papers illustrating and discussing sediment dispersal mechanisms, particularly in mudstones, are recommended for further reading and context to our discussion [33,85-88].

\subsection{Depositional Environment and Controls on Sedimentation in the Late Jurassic}

The present study demonstrates the Kimmeridge Clay Formation in the Cleveland Basin was deposited under marine conditions that had a supply of detrital material. The proportions of the sedimentary components change through the section with the sediment source shifting from predominantly detrital to biogenic, at several intervals (i.e., intervals of high versus low TOC and $\mathrm{CaCO}_{3}$ ). The fine-grained nature of the sediment suggests that deposition occurred in a relatively distal setting, beyond the reach of significant coarse-grained detrital sediment input. Alternatively, the weathered hinterland consisted of soils and clay so there may not have been a source of coarse material. The absence of nearby mountains in palaeogeographic reconstructions, along with an abundance of terrigenous organic material, points towards a finer-grained hinterland instead of a deep-water column. Rivers feeding an epicontinental seaway were likely smaller than modern ones, given the relatively large portion of flooded continent during the Lower Jurassic [78]. Correlation with the section and extrapolation of the cyclostratigraphic framework determined for the Wessex Basin, 
indicates primary controls on sedimentation fluctuated on the order of thousands of years [89]. See Atar et al. [14] for detailed discussion on geochemical evidence for oscillation of depositional environment.

The interpretation from the present study bears strong similarities to that of the coeval section in the Wessex Basin $[10,15]$. Both sections were deposited in a shallow epicontinental seaway and comprise detrital minerals, carbonate, and organic material which vary through time in relative proportion. The comparison between both basins demonstrates the similar processes occurring across space (i.e., $400 \mathrm{~km}$ ), despite slight overall grain size differences. Biological activity was a key driver in the deposition of both successions with algal blooms promoting the production and preservation of carbonate and organic material, and sediment dispersal mechanisms were diverse in both settings. These similarities have been attributed to a global-scale climate belt shift, northerly migration of the intertropical Convergence Zone (ITCZ) and consequential increased storm frequency [23]. The algal blooms, associated with storm activity facilitating water column mixing (Facies 2) may relate to the northward expansion of the ITCZ [14,15,23]; however, further work is required to demonstrate this.

\subsection{Interpreting Geochemical Data in the Context of Petrographic Data}

Petrographic analysis can be a powerful tool when used alongside geochemical data because it provides information of the sediment components, sediment dispersal mechanisms, and burial history of a section, which are all important in characterizing and interpreting sedimentary successions. In the present study, whole-rock geochemical data for each facies exhibits large ranges for each facies (Table 1) [14], partly due to the inevitable averaging of a signal caused by whole-rock geochemical analyses. Consequently, interpretation of geochemical data alone can lead to large uncertainties, loss of detail, and multiple depositional models. For example, petrographic analyses demonstrate there are three forms of carbonate in the studied section; fossil material (coccolithophores, forams, disarticulated macrofossils), carbonate stringers, and dolomite rhombs. The identification of these forms in thin sections aids in interpretation of primary and secondary controls on the sedimentary succession.

\section{Conclusions}

Petrographic analyses were carried out on the Ebberston 87 Core in order to explore the controls on the deposition of a subunit of the KCF. Six facies were identified based on the sedimentary texture, bedding and composition. The facies are defined as (1) clastic detritus-rich medium mudstone, (2) organic material and calcareous pellet-rich laminated mudstone, (3) coccolith-dominated medium mudstone, (4) agglutinated foraminifera-bearing medium to coarse carbonaceous mudstone, (5) biogenic detritus-dominated fine to medium mudstone, and (6) carbonate-cemented fine to medium mudstone. Facies 1 is most common and facies 6 is the rarest (Figure 2).

The sediment in the studied succession comprises marine and terrigenous material and was deposited in a dynamic environment that fluctuated between 'background sedimentation' and bottom current and/or storm influenced sedimentation. Background sedimentation comprised detrital minerals, terrestrial organic matter $(\mathrm{OM})$, and occasional carbonate material. During background sedimentation, algal material was produced, as seen in organo-mineral aggregates, but was poorly preserved. More resistant terrestrial organic material was the highest proportion of organic material (TOC levels of $2-5 \mathrm{wt} \%$ ) in these intervals as indicated by petrographic observations and carbon isotope data. The production of biogenic (algal macerals and coccoliths) material proliferated at several intervals, possibly promoted by storm activity, leading to exceptionally high TOC contents. Dominant processes affecting the sediment composition and depositional environment varied through time as demonstrated by switches between homogenised, detrital-dominated sediment (Facies 1 and 5) that was deposited under oxic to suboxic conditions and pelleted, biological component-dominated sediment (Facies 2, 3, and 4) that was deposited under highly productive water columns, with anoxic sediment pore waters, and that underwent sediment remobilisation. Comparison of this section to a coeval study in the Wessex Basin reaffirms strong similarities between processes in the two basins, suggesting the processes 
were laterally extensive and driven by an over-arching climate control suggested to be an expanded Intertropical Convergence Zone [23].

Author Contributions: Conceptualization, E.A., A.C.A., V.L.-V., C.M., and T.W.; Writing-original draft preparation, E.A.; Writing-review and editing, A.C.A., V.L.-V., C.M., and T.W. All authors have read and agreed to the published version of the manuscript.

Funding: The work contained in this publication was undertaken during a $\mathrm{PhD}$ that was funded by Durham University as part of the Natural Environment Research Council (NERC) Centre for Doctoral Training (CDT) in Oil \& Gas (grant number NEM00578X/1), whose support is gratefully acknowledged.

Acknowledgments: We thank Liam Herringshaw for assistance in sampling the core. Ian Chaplin and Sophie Edwards are thanked for thin section preparation. Leon Bowen is thanked for SEM training and assistance. We gratefully acknowledge IFPEN for proving the Ebberston 87 Core material. We gratefully acknowledge the International Association of Sedimentologists for a postgraduate grant award used for the preparation of thin sections.

Conflicts of Interest: The authors declare no conflict of interest. The funders had no role in the design of the study; in the collection, analyses, or interpretation of data; in the writing of the manuscript, or in the decision to publish the results.

\section{References}

1. Britain, G.S.O.G.; Fox-Strangways, C.; Woodward, H.B. The Jurassic Rocks of Britain; HM Stationery Office, Eyre and Spottiswoode: London, UK, 1892; Volume 1.

2. Arkell, W.J. The Jurassic System in Great Britain. Geogr. J. 1934, 84, 85. [CrossRef]

3. Gallois, R.W. Coccolith blooms in the Kimmeridge Clay and origin of North Sea Oil. Nature 1976, 259, 473-475. [CrossRef]

4. Wignall, P.B. Sedimentary dynamics of the Kimmeridge Clay: Tempests and earthquakes. J. Geol. Soc. 1989, 146, 273-284. [CrossRef]

5. Herbin, J.P.; Muller, C.; Geyssant, J.; Melieres, F.; Penn, I. Heterogeneity of organic matter distribution in relation to a transgressive systems tract: Kimmeridge Clay (Jurassic), England. In Proceedings of the Annual Meeting of the American Association of Petroleum Geologists (AAPG), Dallas, TX, USA, 7-10 April 1991.

6. Morgans-Bell, H.S.; Coe, A.L.; Hesselbo, S.P.; Jemkyns, H.C.; Weedon, G.P.; Marsha, J.E.A.; Tyson, R.V.; Williams, C.J. Integrated stratigraphy of the Kimmeridge Clay Formation (Upper Jurassic) based on exposures and boreholes in south Dorset, UK. Geol. Mag. 2001, 138, 511-539. [CrossRef]

7. Cope, J.C.W. Detailed stratigraphy of the uppermost Kimmeridge Clay Formation (Upper Jurassic) from the Swanworth Boreholes, Dorset, UK. Proc. Geol. Assoc. 2015, 126, 100-106. [CrossRef]

8. Macquaker, J.H.S.; Gawthorpe, R.L. Mudstone lithofacies in the Kimmeridge Clay Formation, Wessex Basin, southern England: Implications for the origin and controls of the distribution of mudstones. J. Sediment. Res. 1993, 63, 1129-1143. [CrossRef]

9. Macquaker, J.H.S.; Keller, M.A.; Davies, S.J. Algal blooms and marine snow: Mechanisms that enhance preservation of organic carbon in ancient fine-grained sediments. J. Sediment. Res. 2010, 80, 934-942. [CrossRef]

10. Lazar, O.R.; Bohacs, K.M.; Schieber, J.; Macquaker, J.H.S.; Demko, T.M. Mudstone Primer: Lithofacies Variations, Diagnostic Criteria, and Sedimentologic-Stratigraphic Implications at Lamina to Bedset Scales; SEPM (Society for Sedimentary Geology): Tulsa, OK, USA, 2015; ISBN 1-56576-341-6.

11. Farrimond, P.; Comet, P.; Eglinton, G.; Evershed, R.P.; Hall, M.A.; Park, D.W.; Wardroper, A.M.K. Organic geochemical study of the Upper Kimmeridge Clay of the Dorset type area. Mar. Pet. Geol. 1984, 1, 340-354. [CrossRef]

12. Jenkyns, H.C.; Hesselbo, S.P.; Jones, C.E.; GrÖcke, D.R.; Parkinson, D.N. Chemostratigraphy of the Jurassic System: Applications, limitations and implications for palaeoceanography. J. Geol. Soc. 2002, 159, 351-378. [CrossRef]

13. Hesselbo, S.P.; Deconinck, J.-F.; Huggett, J.M.; Morgans-Bell, H.S. Late Jurassic palaeoclimatic change from clay mineralogy and gamma-ray spectrometry of the Kimmeridge Clay, Dorset, UK. J. Geol. Soc. 2009, 166, 1123-1133. [CrossRef] 
14. Atar, E.; März, C.; Aplin, A.; Dellwig, O.; Herringshaw, L.G.; Lamoureux-Var, V.; Leng, M.J.; Schnetger, B.; Wagner, T. Dynamic climate-driven controls on the deposition of the Kimmeridge Clay Formation in the Cleveland Basin, Yorkshire, UK. Clim. Past Discuss. 2019, 15, 1581-1601. [CrossRef]

15. Atar, E.; März, C.; Schnetger, B.; Wagner, T.; Aplin, A.C. Local to global controls on the deposition of organic-rich muds across the Late Jurassic Laurasian Seaway. J. Geol. Soc. 2019, 176, 1143-1153. [CrossRef]

16. Arkell, W.J. The Zones of the Upper Jurassic of Yorkshire. Proc. Yorks. Geol. Soc. 1944, 25, 339-358. [CrossRef]

17. Cope, J.C. The ammonite faunas and stratigraphy of the upper part of the Upper Kimmeridge Clay of Dorset. Palaeontology 1978, 21, 469-533.

18. Wignall, P.B. The stratigraphy of the Upper Kimmeridge Clay (late Jurassic) of Golden Hill, Vale of Pickering, North Yorkshire. Proc. Yorks. Geol. Soc. 1993, 49, 207-214. [CrossRef]

19. Lees, J.A.; Bown, P.R.; Young, J.R.; Riding, J.B. Evidence for annual records of phytoplankton productivity in the Kimmeridge Clay Formation coccolith stone bands (Upper Jurassic, Dorset, UK). Mar. Micropaleontol. 2004, 52, 29-49. [CrossRef]

20. Valdes, P. Atmospheric General Circulation Models of the Jurassic. Philos. Trans. R. Soc. B Biol. Sci. 1993, 341, 317-326. [CrossRef]

21. Valdes, P.J.; Sellwood, B.W.; Price, G.D. Modelling Late Jurassic Milankovitch climate variations. Geol. Soc. Lond. Spéc. Publ. 1995, 85, 115-132. [CrossRef]

22. Sellwood, B.; Valdes, P.J. Jurassic climates. Proc. Geol. Assoc. 2008, 119, 5-17. [CrossRef]

23. Armstrong, H.A.; Wagner, T.; Herringshaw, L.G.; Farnsworth, A.J.; Lunt, D.J.; Harland, M.; Imber, J.; Loptson, C.; Atar, E.F.L. Hadley circulation and precipitation changes controlling black shale deposition in the Late Jurassic Boreal Seaway. Paleoceanography 2016, 31, 1041-1053. [CrossRef]

24. Trabucho-Alexandre, J. Organic Matter-Rich Shale Depositional Environments. In Fundamentals of Gas Shale Reservoirs; John Wiley \& Sons, Inc.: Hoboken, NJ, USA, 2015; pp. 21-45. ISBN 978-1-119-03922-8.

25. Macquaker, J.H.S.; Bohacs, K.M. On the Accumulation of Mud. Science 2007, 318, 1734-1735. [CrossRef] [PubMed]

26. Trabucho-Alexandre, J.; Hay, W.W.; de Boer, P.L. Phanerozoic environments of black shale deposition and the Wilson Cycle. Solid Earth 2012, 3, 29-42. [CrossRef]

27. Trabucho-Alexandre, J. More gaps than shale: Erosion of mud and its effect on preserved geochemical and palaeobiological signals. Geol. Soc. Lond. Spéc. Publ. 2014, 404, 251-270. [CrossRef]

28. Schieber, J. Microbial mats in terrigenous clastics: The challenge of identification in the rock record. PALAIOS 1999, 14, 3. [CrossRef]

29. Macquaker, J.H.S.; Taylor, K.G.; Gawthorpe, R.L. High-Resolution Facies Analyses of Mudstones: Implications for Paleoenvironmental and Sequence Stratigraphic Interpretations of Offshore Ancient Mud-Dominated Successions. J. Sediment. Res. 2007, 77, 324-339. [CrossRef]

30. Schieber, J.; Southard, J.; Thaisen, K. Accretion of Mudstone Beds from Migrating Floccule Ripples. Science 2007, 318, 1760-1763. [CrossRef]

31. Davies, S.J.; Leng, M.J.; Macquaker, J.H.S.; Hawkins, K. Sedimentary process control on carbon isotope composition of sedimentary organic matter in an ancient shallow-water shelf succession. Geochem. Geophys. Geosyst. 2012, 13, 13. [CrossRef]

32. Plint, A.G.; Macquaker, J.H.S.; Varban, B.L. Bedload Transport of Mud Across A Wide, Storm-Influenced Ramp: Cenomanian-Turonian Kaskapau Formation, Western Canada Foreland Basin. J. Sediment. Res. 2012, 82, 801-822. [CrossRef]

33. Könitzer, S.F.; Davies, S.J.; Stephenson, M.H.; Leng, M.J. Depositional controls on mudstone lithofacies in a basinal setting: Implications for the delivery of sedimentary organic matter. J. Sediment. Res. 2014, 84, 198-214. [CrossRef]

34. Lazar, O.R.; Bohacs, K.M.; Macquaker, J.H.S.; Schieber, J.; Demko, T.M. Capturing key attributes of fine-grained sedimentary rocks in outcrops, cores, and thin sections: Nomenclature and description guidelines. J. Sediment. Res. 2015, 85, 230-246. [CrossRef]

35. Dera, G.; Brigaud, B.; Monna, F.; Laffont, R.; Pucéat, E.; Deconinck, J.-F.; Pellenard, P.; Joachimski, M.M.; Durlet, C. Climatic ups and downs in a disturbed Jurassic world. Geology 2011, 39, 215-218. [CrossRef]

36. Turner, H.E.; Gradstein, F.M.; Gale, A.S.; Watkins, D.K. The age of the Tojeira Formation (Late Jurassic, Early Kimmeridgian), of Montejunto, west-central Portugal. Swiss J. Palaeontol. 2017, 136, 287-299. [CrossRef] 
37. Turner, H.E.; Batenburg, S.; Gale, A.S.; Gradstein, F.M. The Kimmeridge Clay Formation (Upper Jurassic-Lower Cretaceous) of the Norwegian Continental Shelf and Dorset, UK: A chemostratigraphic correlation. Newsl. Strat. 2019, 52, 1-32. [CrossRef]

38. Koevoets, M.J.; Abay, T.B.; Hammer, Ø.; Olaussen, S. High-resolution organic carbon-isotope stratigraphy of the Middle Jurassic-Lower Cretaceous Agardhfjellet Formation of central Spitsbergen, Svalbard. Palaeogeogr. Palaeoclim. Palaeoecol. 2016, 449, 266-274. [CrossRef]

39. Koevoets, M.J.; Hammer, Ø.; Olaussen, S.; Senger, K.; Smelror, M. Integrating subsurface and outcrop data of the Middle Jurassic to Lower Cretaceous Agardhfjellet Formation in central Spitsbergen. Nor. J. Geol. 2018, 98, 1-34. [CrossRef]

40. Dalland, A.; Worsley, D.; Ofstad, K. A lithostratigraphic Scheme for the Mesozoic and Cenozoic and Succession Offshore Mid-and Northern Norway; Oljedirektoratet: Stavanger, Norway, 1988.

41. Hammer, Ø.; Collignon, M.; Nakrem, H.A. Organic carbon isotope chemostratigraphy and cyclostratigraphy in the Volgian of Svalbard. Nor. J. Geol. 2012, 92, 103-112.

42. Moshrif, M.A. Sequential Development of Hanifa Formation (upper Jurassic) Paleocnvironments and Paleogeography, Central Saudi Arabia. J. Pet. Geol. 1984, 7, 451-460. [CrossRef]

43. Huang, Z.; Williamson, M.A.; Fowler, M.G.; McAlpine, K.D. Predicted and measured petrophysical and geochemical characteristics of the Egret Member oil source rock, Jeanne d'Arc Basin, offshore eastern Canada. Mar. Pet. Geol. 1994, 11, 294-306. [CrossRef]

44. Riboulleau, A.; Derenne, S.; Sarret, G.; Largeau, C.; Baudin, F.; Connan, J. Pyrolytic and spectroscopic study of a sulphur-rich kerogen from the "Kashpir oil shales" (Upper Jurassic, Russian platform). Org. Geochem. 2000, 31, 1641-1661. [CrossRef]

45. Pathak, D.B. Jurassic/Cretaceous boundary in the Spiti Himalaya, India. J. Palaeontol. Soc. India 2007, 52, 51-57.

46. Hakimi, M.H.; Abdullah, W.H.; Shalaby, M.R. Source rock characterization and oil generating potential of the Jurassic Madbi Formation, onshore East Shabowah oilfields, Republic of Yemen. Org. Geochem. 2010, 41, 513-521. [CrossRef]

47. Hammes, U.; Hamlin, H.S.; Ewing, T.E. Geologic analysis of the Upper Jurassic Haynesville Shale in east Texas and west Louisiana. AAPG Bull. 2011, 95, 1643-1666. [CrossRef]

48. Gallois, R.W.; Medd, A.W. Coccolith-rich marker bands in the English Kimmeridge Clay. Geol. Mag. 1979, 116, 247-260. [CrossRef]

49. Cox, B.M.; Gallois, R.W. The Stratigraphy of the Kimmeridge Clay of the Dorset Type Area and Its Correlation with Some Other Kimmeridgian Sequences; HMSO: Norwich, UK, 1981; Volume 80, ISBN 0-11-884182-3.

50. Korte, C.; Hesselbo, S.P.; Ullmann, C.V.; Dietl, G.; Ruhl, M.; Schweigert, G.; Thibault, N. Jurassic climate mode governed by ocean gateway. Nat. Commun. 2015, 6, 10015. [CrossRef] [PubMed]

51. Rawson, P.F.; Wright, J.K. The Yorkshire Coast. In The Yorkshire Coast Geologists' Association Guide No. 34; Geologists' Association: London, UK, 2000; p. 117.

52. Powell, J.H. Jurassic sedimentation in the Cleveland Basin: A review. Proc. Yorks. Geol. Soc. 2010, 58, $21-72$. [CrossRef]

53. Bradshaw, M.J.; Cope, J.C.W.; Cripps, D.W.; Donovan, D.T.; Howarth, M.K.; Rawson, P.F.; West, I.M.; Wimbledon, W.A. Jurassic. Geol. Soc. Lond. Mem. 1992, 13, 107-129. [CrossRef]

54. Hallam, A. Jurassic Environments; Cambridge University Press: Cambridge, UK, 1975; ISBN 0-521-12906-0.

55. Aigner, T. Biofabrics and stratinomy of the Lower Kimmeridge Clay (U. Jurassic, Dorset, England). Neues Jahrb. Geol. Paläontol. Abh. 1980, 159, 324-338.

56. Oschmann, W. Kimmeridge clay sedimentation-A new cyclic model. Palaeogeogr. Palaeoclimatol. Palaeoecol. 1988, 65, 217-251. [CrossRef]

57. Haq, B.U.; Hardenbol, J.; Vail, P.R. Mesozoic and Cenozoic chronostratigraphy and cycles of sea-level change. Sea Level Chang. 1988, 71-108. [CrossRef]

58. Boussafir, M.; Gelin, F.; Lallier-Vergès, E.; Derenne, S.; Bertrand, P.; Largeau, C. Electron microscopy and pyrolysis of kerogens from the Kimmeridge Clay Formation, UK: Source organisms, preservation processes, and origin of microcycles. Geochim. Cosmochim. Acta 1995, 59, 3731-3747. [CrossRef]

59. Herbin, J.P.; Geyssant, J.R. Organic belts during Kimmeridgian/Tithonian in England (Yorkshire, Dorset) and France (Boulonnais). Comptes Rendus L'academie Sci. Seris II 1993, 317, 1309-1316. 
60. Herbin, J.P.; Fernandez-Martinez, J.L.; Geyssant, J.R.; Albani, A.E.; Deconinck, J.F.; Proust, J.N.; Colbeaux, J.P.; Vidier, J.P. Sequence stratigraphy of source rocks applied to the study of the Kimmeridgian/Tithonian in the north-west European shelf (Dorset/UK, Yorkshire/UK and Boulonnais/France). Mar. Pet. Geol. 1995, 12, 177-194. [CrossRef]

61. Boussafir, M.; Lallier-Vergès, E. Accumulation of organic matter in the Kimmeridge Clay formation (KCF): An update fossilisation model for marine petroleum source-rocks. Mar. Pet. Geol. 1997, 14, 75-83. [CrossRef]

62. Lallier-Vergès, E.; Hayes, J.M.; Boussafir, M.; Zaback, D.A.; Tribovillard, N.P.; Connan, J.; Bertrand, P. Productivity-induced sulphur enrichment of hydrocarbon-rich sediments from the Kimmeridge Clay Formation. Chem. Geol. 1997, 134, 277-288. [CrossRef]

63. Tribovillard, N.-P.; Desprairies, A.; Lallier-Vergès, E.; Bertrand, P.; Moureau, N.; Ramdani, A.; Ramanampisoa, L. Geochemical study of organic-matter rich cycles from the Kimmeridge Clay Formation of Yorkshire (UK): Productivity versus anoxia. Palaeogeogr. Palaeoclim. Palaeoecol. 1994, 108, 165-181. [CrossRef]

64. Tribovillard, N. Controls on organic accumulation in Upper Jurassic shales of northwestern Europe as inferred from trace-metal geochemistry. Depos. Org. Carbon Rich Sediments Models 2005, 145-164. [CrossRef]

65. Herbin, J.P.; Müller, C.; Geyssant, J.R.; Mélières, F.; Penn, I.E.; Group, Y. Variation of the distribution of organic matter within a transgressive system tract: Kimmeridge Clay (Jurassic), England. Source Rocks Seq. Stratigr. Framew. 1993, 67-100. [CrossRef]

66. Williams, C.J.; Hesselbo, S.P.; Jenkyns, H.C.; Morgans-Bell, H.S. Quartz silt in mudrocks as a key to sequence stratigraphy (Kimmeridge Clay Formation, Late Jurassic, Wessex Basin, UK). Terra Nova 2001, 13, 449-455. [CrossRef]

67. Gradstein, F.M.; Ogg, J.G.; Schmitz, M.; Ogg, G. The Geologic Time Scale 2012; Elsevier: Oxford, UK, 2012; ISBN 0-444-59448-5.

68. Savrda, C.E.; Bottjer, D.J. Trace-fossil model for reconstruction of paleo-oxygenation in bottom waters. Geology 1986, 14, 3-6. [CrossRef]

69. Dashtgard, S.E.; MacEachern, J.A. Unburrowed mudstones may record only slightly lowered oxygen conditions in warm, shallow basins. Geology 2016, 44, 371-374. [CrossRef]

70. Tribovillard, N.; Koched, H.; Baudin, F.; Adatte, T.; Delattre, M.; Abraham, R.; Ferry, J.-N. Storm-induced concentration of sulfurized, marine-origin, organic matter as a possible mechanism in the formation of petroleum source-rock. Mar. Pet. Geol. 2019, 109, 808-818. [CrossRef]

71. Turner, J.T. Zooplankton fecal pellets, marine snow, phytodetritus and the ocean's biological pump. Prog. Oceanogr. 2015, 130, 205-248. [CrossRef]

72. Irwin, H.; Curtis, C.; Coleman, M. Isotopic evidence for source of diagenetic carbonates formed during burial of organic-rich sediments. Nature 1977, 269, 209-213. [CrossRef]

73. Vasconcelos, C.; McKenzie, J.A.; Bernasconi, S.; Grujic, D.; Tiens, A.J. Microbial mediation as a possible mechanism for natural dolomite formation at low temperatures. Nature 1995, 377, 220-222. [CrossRef]

74. Van Lith, Y.; Warthmann, R.; Vasconcelos, C.; McKenzie, J.A. Sulphate-reducing bacteria induce low-temperature Ca-dolomite and high Mg-calcite formation. Geobiology 2003, 1, 71-79. [CrossRef]

75. Jeans, C.V. Clay mineralogy of the Jurassic strata of the British Isles. Clay Miner. 2006, 41, 187-307. [CrossRef]

76. Hillier, S.; Wilson, M.J.; Merriman, R.J. Clay mineralogy of the Old Red Sandstone and Devonian sedimentary rocks of Wales, Scotland and England. Clay Miner. 2006, 41, 433-471. [CrossRef]

77. McManus, D.A. Modern versus relict sediment on the continental shelf. Geol. Soc. Am. Bull. 1975, 86, 1154-1160. [CrossRef]

78. Schieber, J. Mud re-distribution in epicontinental basins - Exploring likely processes. Mar. Pet. Geol. 2016, 71, 119-133. [CrossRef]

79. Pedersen, T.F.; Calvert, S.E. Anoxia vs. Productivity: What Controls the Formation of Organic-Carbon-Rich Sediments and Sedimentary Rocks? (1). AAPG Bull. 1990, 74, 454-466. [CrossRef]

80. Potter, P.E.; Maynard, J.B.; Depetris, P.J. Mud and Mudstones: Introduction and Overview; Springer Science \& Business Media: Berlin, Germany, 2005; ISBN 3-540-27082-5.

81. Katz, B.J. Controlling factors on source rock development-a review of productivity, preservation, and sedimentation rate. Soc. Sediment. Geol. 2005, 7-16. [CrossRef]

82. Liu, J.T.; Hsu, R.T.; Yang, R.J.; Wang, Y.P.; Wu, H.; Du, X.; Li, A.; Chien, S.C.; Lee, J.; Yang, S.; et al. A comprehensive sediment dynamics study of a major mud belt system on the inner shelf along an energetic coast. Sci. Rep. 2018, 8, 4229. [CrossRef] [PubMed] 
83. Zhang, W.; Cui, Y.; Santos, A.I.; Hanebuth, T.J. Storm-driven bottom sediment transport on a high-energy narrow shelf (NW Iberia) and development of mud depocenters. J. Geophys. Res. Ocean. 2016, 121, 5751-5772. [CrossRef]

84. Shanks, A.L. The abundance, vertical flux, and still-water and apparent sinking rates of marine snow in a shallow coastal water column. Cont. Shelf Res. 2002, 22, 2045-2064. [CrossRef]

85. Stow, D.; Mike Mayall, M. Deep-water sedimentary systems: New models for the 21st century. Mar. Pet. Geol. 2000, 17, 125-135. [CrossRef]

86. Ghadeer, S.G.; Macquaker, J.H.S. Sediment transport processes in an ancient mud-dominated succession: A comparison of processes operating in marine offshore settings and anoxic basinal environments. J. Geol. Soc. 2011, 168, 1121-1132. [CrossRef]

87. Boulesteix, K.; Poyatos-Moré, M.; Hodgson, D.M.; Flint, S.; Taylor, K.G. Fringe or background: Characterizing deep-water mudstones beyond the basin-floor fan sandstone pinchout. EarthArXIV 2019. [CrossRef]

88. Hamlyn, R.; Boulesteix, K.; Taylor, K.; Flint, S.; Jerrett, R. Shallow-water Mudstone Architecture and Depositional Process Variability: Evidence for Heterogeneity at Kilometre-scale. EarthArXiv 2020. [CrossRef]

89. Huang, C.; Hesselbo, S.P.; Hinnov, L. Astrochronology of the late Jurassic Kimmeridge Clay (Dorset, England) and implications for Earth system processes. Earth Planet. Sci. Lett. 2010, 289, 242-255. [CrossRef]

Publisher's Note: MDPI stays neutral with regard to jurisdictional claims in published maps and institutional affiliations.

(C) 2020 by the authors. Licensee MDPI, Basel, Switzerland. This article is an open access article distributed under the terms and conditions of the Creative Commons Attribution (CC BY) license (http://creativecommons.org/licenses/by/4.0/). 